
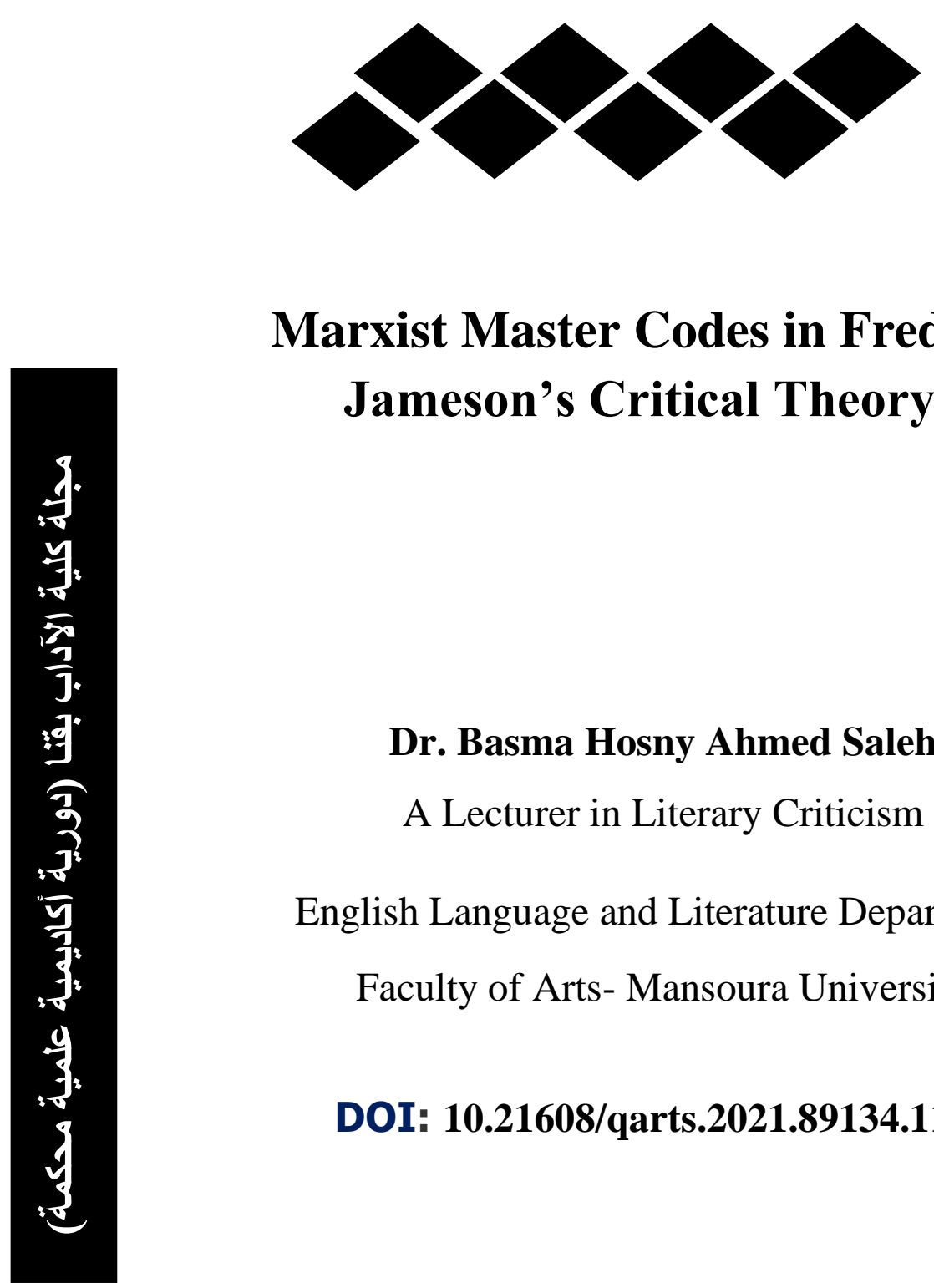

\title{
Marxist Master Codes in Fredric Jameson's Critical Theory
}

\author{
Dr. Basma Hosny Ahmed Saleh \\ A Lecturer in Literary Criticism
}

English Language and Literature Department Faculty of Arts- Mansoura University

DOI: 10.21608/qarts.2021.89134.1179

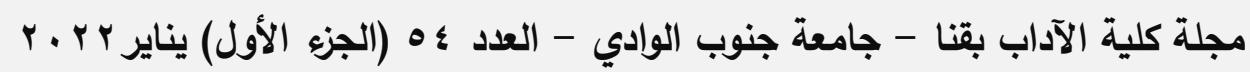
ISSN (Print): 1110-614X الترقيم الدولي الموحد للنسخة المطبوعة ISSN (Online): 1110-709X الترقيم الدولي الموحد للنسخة الإكترونية الإولي

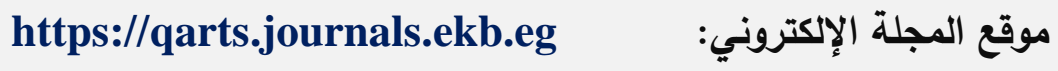




\section{Marxist Master Codes in Fredric}

\section{Jameson's Critical Theory}

Prepared by

\section{Dr. Basma Honsy Ahmed Saleh}

A Lecturer in Literary Criticism

English Language and Literature Department

Faculty of Arts- Mansoura University

salehbasma66@gmail.com

\section{Abstract}

Fredric Jameson starts his highly informative book The Political Unconscious with Wittgenstein's statement: "To imagine a language means to imagine a form of life." For Jameson, this imaginative process is one of allegorical reading, rewriting, and interpretation based upon choosing a master code in light of which the reader reshapes the text. In this respect, not only literature but also and in a more effective manner criticism is seen as an endlessly imaginative and human process of reshaping the world in an ideological subjective way. The question is where do these endless ideological interpretations which reshape the pre-written course lead? Are they capable of getting us to a universal and an embracing perspective that has the aura of objective validity? This paper intends to propose a speculation of Jameson`s view to answer these questions. In expounding his critical theory, the paper hypothesizes that Jameson's main focus is the idea of a master code he finds in Marxism which he considers a transcendental supreme demystification of reality. Applying a historicist and dialectic criticism he adopts not only in his The Political Unconscious but throughout his criticism, the paper attempts to prove that his 
Marxist approach is nothing but an ethical and religious one following the dialectic of absence and presence similar to Althusser's historiographical project of the production of the object.

Keywords: ideology, hermeneutics, utopia, historicism, dialectics. 
This paper aims at investigating Fredric Jameson`s Marxist approach to his three main apparently abstract but turning into imaginative preoccupations: history, culture, and the literary work in an attempt to conceptualize how dialectics is the constricting mechanism that binds these areas of interrogation, only to extend them in an imaginary world of meta-narrative. This wider imaginary horizon is the transcode of Marxism which includes the dialectic-painted images of ideology, utopia, and historicism. Jameson has always repeated that reading and narration is the instinctive function of the human mind. In this respect, the imaginary articulations of man in terms of history or culture or literature are seen as man`s distinctive feature, his own straight line of narration that enables him to create parallel expanded worlds of historicism, ideology and utopia. It is a world in which his imagination grants him a position of an omniscient author or absolute authority, using Deleuse's definition, practicing the freedom of a folding process between the two parallel dimensions of syllogism and life, of negation or absence and presence. In short, it is a world that proceeds with his own command of what should be and what shouldn't be. It is an imaginative play similar to the Da- Forte game practiced by the child in the absence of his mother, but in the hands of the Absolute it is the whole ontology of man.

Dialectics, as the basic Marxist mechanism, is essentially the beating heart of Jameson`s world with its consecutive constricting and extending pulsation revealing its life movement to be no more than two alternative convex and concave mirrors he uses to relate the six concerned areas in an ontological scheme or a political unconscious. This political unconscious is mainly Jameson's scientific aspiration towards drawing a cognitive map; a systematic inventory of historical, cultural and literary forms and a similar 
hidden history of the various forms and modes of subjectivity (Jameson: A Critical Reader xvi).

Jameson, as Eagleton says, the matchless Marxist critic in versatility, encyclopedic erudition and imaginative brio (Tally Jr. 2) still believes that in this proliferation of codes characteristic of our contemporary world, Marxism should be given a chance as a meta-commentary (Jameson, Ideologies of Theory $\mathrm{x}$ ). In explanation of Jameson`s attack on Modernism, Sean Homer shows how Jameson considers its attempts at innovation and autonomy as ruptures, individual endeavors to cut the collective project that fundamentally both constitutes and changes the world as a system (xviii) Jameson`s long and deep acquaintance with Romance philology and his familiarity with both German and French giant philosophers and authors have enabled him as Buchnan says to avoid the influences of modernism and New Criticism (122-123). Informed by Luckas' History and Class Consciousness, Jameson turns to the opposite direction, to the concept of totalization as a processing system or as an open system that keeps modifying itself to meet the ever-changing nature of its elements (Jameson: A Critical Reader xvi). Consequently, Marxism remains the master narrative of Jameson`s corpus. In this respect, it should be made clear that the word narrative doesn't connote only diachronic history, but also a synchronic one because the Marxist narrative with its two basic areas of investigation, mode of production and class struggle, is seeking the narrativity of the form in both its external collective embodiment and its internal individual shape of historicism, ideology and utopia. The concrete form is both the beginning and the end in this arduous struggle. So what we are left with is an image of Marxism with its unconstructed nature seeking an open 
system whose basic hero, that's form, is always in the process of becoming and Marxism`s main mechanism of investigation in terms of dialectics is of a double convex and concave mirror identity. It is an intricately convoluted plot whose events and characters are of a quick silver nature, but Jameson sees the project as worthy because it has its moments of wresting temporal imaginative freedom out of the world of necessity. Moreover, he believes these moments to be the rehearsal theatre where consciousness is preparing itself for real change and at the same time learns to make demands on the real world (17).

In this respect, the question is: does this meta-commentary which critics suggest as the cornerstone of the entire Jamesonian enterprise have claims to truth? His answer is a clear no, but he isn't looking for truth as much as he is after what should and what shouldn't be said (2). To know what he means and the shadow his approach throws on other restrictive theories of interpretation, his understanding of Marxism, dialectics, and the imaginary should be set forward, a step sure to entwine the other three fields of investigation.

From the very beginning, Jameson states that Marxism is neither a philosophy nor a system or theory. It is an anti-system marking the end of philosophy (Jameson, Marxism and Form 361) for the latter`s strategy is based upon adopting a particular rational system and interpreting the investigated object, be it art, culture, or even history in its light.

Instead of the traditional ready-made structure in which literary or cultural theories try to mold the object in, Jameson declares that any object, the literary text, for example, has its logic, generates its categories, and above all organizes them (333). Evidently, as 
O'Kane says, Jameson is adopting an immanent criticism (Jameson: A Critical Reader 144). For a moment, the Marxist perspective coats itself in a pseudo modern identity of approaching the text with a tabula rasa submitting to its mysterious hidden working mechanism, but Marxist criticism is far from being an accepting ideology to an informative other. In its approach to the cultural, literary, and historical object, it is mainly interested in two things: its mode of production and class struggle (Jameson, Marxism and Form 296). Drawing on this, Fredric Jameson is evidently investigating the multiple and various methods of production in all fields starting from the most abstract ones like being, consciousness, ideas to the most concrete areas like architecture, no wonder that Colin MacCabe refers to his encyclopedic erudition saying "nothing cultural is alien to him" (Jameson: The geopolitical aesthetic ix).

In its meta-narrative tracing of the object's mode of production, Marxist Dialectic passes three basic phases: textual analysis, socio-economic analysis or historiography, and the last phase of coming back to the text in a meta-narrative gesture (Jameson, The Ideologies of Theory $\mathrm{x}$ ). In his Valences of Theory, Jameson announces his intention of tracing the Hegelian, Kantian and Aristotelian progression of forms through Hegel's temporal narrative of being (world of quantities and qualities), essence (world of relations) and notion (world of syllogism and life) (76). Out of a belief that an object doesn't deliver itself to understanding as a totality, but rather as an aggregation of particles related to the subject`s interests, and that this collectivity of particles renders itself as a commodity, establishing relations with other commodities, Marxist criticism seeks no interpretation of these 
relations but their articulations, their visibility (Jameson, Marxism and Form 406).

This aggregation constitutive of the object, be it a historical event, a cultural phenomenon or an artistic text raises itself to man`s consciousness whether a writer or a critic both as a clear content and as an opaque inner form, thus posing a problematic situation for man`s parallel inner world whether the mental or the psychological which is evident to possess a similar duality of content and abstract structures. Naïve reader/writer, as Jameson sees, once encountering this opaque element, relies on the transparency of rational thought (347). Sometimes, the reader/writer goes further and separates the intellectual process and collapses in a tautology. On a higher level, the writer/ reader resorts to symbols from the past or parallel realistic portions of the present to rearticulate the object, but again Jameson reminds that Marxism is against idealism or realism (364) for in this case, we conceive the role of the subject writer/ reader as conferring meaning/form on the object-the work`s content-out of a faulty belief that the content is meaningless. Jameson proposes that the work of art doesn 't confer meaning on the content, but it transforms the initial one, hence his conclusion that neither the creation of the artistic work nor its interpretation is an arbitrary process (402). Jameson`s conclusion is a scientific aspiration towards constricting what cannot be perceived but as a continuity; the continuity of history, imagination, and breathless dialectics behind struggling to perform an intellectual squaring of the material circular continuum.

On the macro level of history, Jameson states that history is the ultimate horizon of interpretation (Jameson: A Critical Reader 3) but it isn `t a text or narrative. It is accessible to us only in textual or narrative form (Ideologies of Theory 151). On the micro- 
level of the work of art, the Marxist approach is behind the narrativity of that form, its mode of production which is based upon a process of stylistic selection informed by socio-economic conditions imposed not on classes, but class conflict. In other words, a multiplicity of styles and techniques are available for the reader/writer to encode his vision or his critical articulation, but the criteria of selecting out these to be his framework are the working of the political unconscious of socio-economic conditions and class conflict. The former establishes the quantity level of what in vulgar Marxism is called infrastructure, while the latter constitutes the quality level of the superstructure which includes man`s intellectual attitude (Marxism and Form 343) reflected in cultural products informed by ideology. Quantity and quality are Aristotelian and Kantian spatial terms translated into the world of being in Hegel's temporal scheme (Jameson, Valences of the Dialectic 77). It is this latter level which marks the Sartrean and Althusserian imaginary realm.

Jameson`s notion that the chosen style is not controlled by class but by class conflict complicates the process for now the reader/writer isn`t dealing with stable entities held in compartments by economic conditions, but rather with a revolutionary mechanism driven by socio-economic powers that Jameson and behind him the western Marxism -in contrast to European Marxism (Flisfeder162) insists on complementing with the historical aspect. Therefore, as Jameson postulates, the concept of class struggle works synchronically and diachronically, in the sense that class conflict is related both to the place and to the participants in the historical process (Jameson, Marxism and Form 385).

Seen this way, the reader/writer`s mission is an intricate one of a revolutionary consciousness characteristic of the Marxist 
approach he epitomizes, an approach that doesn 't accept things at their face value, and a parallel and similar one embodied in either the historical or artistic text. More significant is that both are contained in a socio- economic sphere. This duality, transformed into a triadic on the literary field of reading and writing, finds in Marxist dialectics its master code. Marxist dialectics believes that this duality cannot be transcended or resolved, hence Jameson`s honest rejection of any claims to fathoming an Ultimate truth for Marxism isn't a hermeneutic in the sense of interpretation, but of articulation, of description and understanding. Marxist dialectics is a revelation, a process of laying bare, of restoring the original message, of describing its mechanism of absence and presence, of censorship and domination. Allegorically speaking, Marxism with its basic mechanism of dialectics is heading straight to the heart of darkness, to the original sin based upon a luciferin insinuating idea, leading to expulsion, to an articulated world of eternal dualities. The only outlet is figured in religion and in the playful world of history, literature and culture whose basic dynamic is dialectics which is responsible for generating three parallel forms of historicism, utopia and ideology. Jameson says that the other alternative to Marxist revealing dialectics is an interpretation built upon religious or theological basis, for religion is a set of imaginary propositions believed to be true, if the theoretical consequences of Marxism to be avoided (402). It is important to bear in mind such allegory for a proper understanding of dialectics

It has been stated that each object has its inner logic and that the task of Marxism with its dialectics is to reveal that logic responsible for its final form, but Jameson reminds the reader that this pursued form isn't hermeneutic in a positive sense (401). It doesn't render itself as timelessly associated to the object the way an attribute is related to an object in natural science. In other words, 
this form passes through different stages in its production: economic, historical, intellectual, constituting various and multiple layers till it reaches the final form, delivered as a commodity to the reader/writer. One of the basic characteristics of dialectics is its claims to completeness, in the sense that the subject: reader/writer, should apply, in a manner of labor, ever-widening circles of historical, social, economic and intellectual investigation till he reaches the layer of the object's concrete reality (309). It is evident that the Marxist dialectics is repeating the original sin of revealing the process of creation embedded in the narrative leaves of the forbidden tree. The Marxist repetition of the original sin has served to clarify the hidden fruits of the tree. Still, the full significance of the dialectical mechanism hasn`t been fathomed. Jameson clarifies that dialectical textual analysis characteristic of the first stage is built upon isolating certain factors from the historical continuum; such factors enjoy diachronic interrelations that are necessary for articulation (311). Jameson`s words indicate that the factors referred to enjoy a rarified appearance, a porous physicality covering a period. Whether these factors are traditionally called atoms or monads, or even forms, the practical application of their extraction from the text reveals them to be several serial ideas related in terms of cause and effect. This diachronic distance allows them to breathe through the rest of the literary work or the historical phenomenon on the ontological level. So, the first stage of textual analysis results in many ideas organized in terms of cause and effect. This is the Aristotelian domain of logic which corresponds to the Platonic one of the ideals and the Sartre's existential serial state. From a Sartrean and Jamesian perspective, this is what they choose to call the authentic original social state of being which includes the various folds of the world to come, the temporal world of which it will be a witness, a measuring scale of 
what should and what shouldn`t be and how it should or shouldn't be. The elements of this domain will be just like flickering stars marking what is present in each fold and more important working as shadows or ghosts of what is absent. In Jameson`s analysis, they are the mediators between the various folds of history. Jameson quotes Adorno saying that art owes its existence to the division of labor into physical and mental (408). It can safely be assumed that life, too, and the literary world spring from a similar division between a selected, and abstracted elements that will function as the heavenly ideal and logical horizon for the rest of what could be termed as the earthly elements. It is a human imaginary repetition of the divine creative process "Have not those who disbelieve known that the heavens and the earth were joined together as one piece, then, we parted them? And we made from water every living thing. Will they not believe?'(Qur'an, English, Surah Al - Anbiya, Ayah 30).

Hegelian dialectics attempts a liquidation of this series of ideas in the second stage of historiography by embodying them in social groups belonging to a specific time and place, and here the indeterminacy of distance characteristic of history helps the writer as well as the reader to change the main focus of reality and to see the same as new, which is evidently an imaginary attitude (Jameson, Marxism and Form 344). It is noteworthy that Jameson reminds the reader that if the ancient Greeks have excelled in extracting the ideals from the material world, our task is to do the opposite, in the sense of going through the opposite journey of tracing how the forms are transformed into material elements ( Jameson, Valences of the Dialectic 181). Ironically, this is what the usually misconceived idealist philosophy of Hegel is doing and Marxism is just a follower. This being the case, it is evident that Marxism is considering both the abstracted few and the rest on 
equal materialist scales. History will be just like zoom lens in the hands of the reader/writer with his point of view, characterization, and plot. So, in a sense history is embodying the convex and concave double nature of the beating heart of dialectics. This second Hegelian stage has its parallel in Sartre`s philosophy of group formation in terms of alternative sequences of circles and series (Jameson, Marxism and Form 283).

The second stage of Marxist dialectics marks, as the aforementioned explanation shows, the working of the imaginative abilities because, among the basic functions of dialectics and included in its revealing the reality is spotting censorship. The fact is that it is this omitted part which is the mainspring of the Marxist revolutionary aspect. This repulsive aspect is what Sartre calls consciousness or nothingness or lack of being on the ontological level. As Sartre, following Freud and Kant, explains that everything in life is directed towards the gratification or the relief of that part (268). History of the literary and critical schools is a repertoire of how different minds labored to gratify it, or to use a linguistic terminology to find out its code, thus feeling satisfied. But Marxism with its basic tool of dialectics has managed to do the opposite, namely to maintain its empty form simply because it is everything and nothing, in the sense that it has endless possibilities for the real and at the same time it is no home for any of them. Hence, Jameson`s definition of the dialectics as working underground as a differential perception (311). So contrary to other theories which have tried a strategy of containment concerning this spot, ending with one-sided vision that suppresses all other sides, Marxism has made of it a transcode through which it temporally sets contraries or selects opposites, and instead of transcending them, it reverses them, reading the abstract and invisible in terms of its concrete 
counterpart, and reorganizing the whole in a new imaginative metacommentary: the third stage of dialectic criticism.

Here, we should reflect upon the difference between the Marxist material approach and the other, if we are allowed to use the term, more comforting approaches adopted by other critical theories concerning the idea of censorship or lack. Most theories consider this lack, or omitted part in terms of an existential station, in the sense that theorists are obligated to stop at and try to satisfy with its opposite, be it desire, structure, archetype, or phenomena which will accompany them in all their interpretations concerning other texts. Marxism, on the other hand, considers lack in functional terms, in the sense that it has a mediating mission between the visible and a third meta-level. Most important is that it sees this invisible or lack in materialist terms, just like the visible with which it operates a sort of translation or mediation for the third meta-level to be articulated. The only difference between the world of lack and that of reality is visibility. They are the form and the content of the same thing, and dialectics is just a code-switching mode, reading one in terms of the other. Juxtaposing the two results in what Jameson believes to be an electrical shock (400). Here, we should stop and ponder over this resulting shock. The second stage of liquidating the abstracted world of being into the socioeconomic one marks the confrontation between being and nothingness, because in the process of liquidation, certain elements are destined to show face while others suffer a sort of eclipse. It is a shock of the heavenly world of abundant qualities and quality facing the earthly world of relations or what Hegel calls essence based upon cutting and patching, losing part for the total picture to be formulated. Syntactically speaking, it is a war between a world of subjectivity and full light, a world of phonemes, with a world of predication that cuts to form a narrative of subjectivity in terms of 
collaborating cut and pieced allophones. Jameson quotes Hegel saying

If the opposition in thought is stated in this immediacy as Being and Nothingness, the shock of its nullity is too great not to stimulate the attempt to fix Being and to secure it against the transition into Nothingness. With this intent, the reflection has recourse to the plan of discovering some fixed predicate for Being, to mark it off from Nothingness. Thus, we find Being identified with what persists amid all change, with matter (qtd. in Jameson, Valences of the Dialectic 85)

This shock is responsible for raising the process of historical or critical or even ontological interpretation to a higher level of articulation, which is sure a leveling mid-way between the two.

The fore mentioned explanation creates of dialectics a valence process built upon man submitting his intellectual abilities to the boundaries of his material essence, the specific material essence of the number of factors he has chosen in the first stage to be the participant in the second stage of dialectics where it is juxtaposed to the general material totality of the visible. It is a process recalling to the mind the story of the murdered man and the divine order of butchering a cow and beating the man with part of it so that the dead are resurrected to speak of the murderer (Qur'an, English, Al- Baqara, Ayah 73).

This second stage of dialectical criticism drives the reader to the wider horizon of morals and religion because, in the meeting of the censored individual part as the latent content with the visible collective dominating form of the rest of the literary text or its socio-economic conditions, Marxism is multiplying the dimensions 
of the individual, thus giving it value ( Jameson, Marxism and Form 390) In another context, Jameson defines religion as reliving wartime of togetherness with morals (406). He perceives in such juxtaposition a process of enabling the individual to get outside himself and to see the familiar as an alienated structure, a withdrawn glove, a serial number (278). In the Political Unconscious, Jameson states the working of his mind about the shadows that Marxism may throw over Christian historicism

Any comparison of Marxism with religion is a two-way street, in which the former isn't necessarily discredited by its association with the latter. On the contrary, such a comparison may also function to rewrite certain religious concepts-most notably Christian historicism and the concept of providence, but also the pre theological system of primitive magic-as anticipatory forebodings of historical materialism with pre-capitalist social formations in which scientific thinking is unavoidable as such (275).

The above quotation is essential in considering, not the ethical perspective of Marxism, which is ready to reread every text, even religious ones in its dialectical strategy, but Jameson`s moral conception of the hidden relation between the pre theological system of magic and the historical materialism of capitalist and pre-capitalist societies with its belief in science and immediate individual gain. In The Ideologies of Theory, he unveils the basic difference between priests and magicians. Both stand for examples of mediatory links between the individual and the collective, but while the latter is after quick immediate profit, the former's mediation is contained, entwined with the universal principles and directed for the collective benefit or interest (15). In deconstructive terms, it may be said that Jameson is endeavoring a 
delayed or differed significance and benefit. After all, it implies labor through different layers of significance, a sort of continuous praxis of a theory that keeps changing because its determining principle is the eternally changing socio-economic conditions. Now, the question is what is the end of this endless process of, for example reading a specific period of history or a cultural phenomenon in terms of ever-widening circles of synchronic and diachronic similar or opposite ones? More perplexing is the idea that doesn't this method jeopardizes the exact value of things, making them elastic with the concave and convex lens we use reading them?

The answer to these questions is both a Marxist and a Hegelian one wrapped in the imaginary realm. In line with the Marxist belief that history is false because it is written by the dominant class ideology, Jameson is proposing a Benjaminian project of cognitive mapping which rereads history or culture including literature in terms of the invisible, thus as he says it becomes like Tiresias, once fed upon the blood of the collective socio-economic, is nurtured and allowed to speak. He believes that this cognitive mapping of the political unconscious knows how to draw the exact dimensions because of two things, the first of which is what Marxists call historical inevitability. The term denotes a feeling accompanying the analyst that why things happened that way and no other way ( Jameson, Marxism and Form 360). Second, he believes that this ever-widening process of reading enriches the value of particular phenomena or periods or writers. Such an enriching process should be going on until the Hegelian Absolute appears with the Sunday of life when life is incapable of rejuvenating itself (364). On the particular individual level, this is the stage where all content reaches its ideal form or 
archetype, for as Jameson says the archetype is not the initial form, but the final articulation (328).

Now, it is time to see how Jameson has managed to make of dialectic the Platonic world of geometry connecting the world of ideals to that of reality, and more important how this double faced coin of geometry and dialectic is nothing but the free imaginary realm Jameson has wrested from the world of necessity. Sartre's existential Marxism has been the main focus of Jameson`s Ph.D. thesis, and it is evident that it has left its lasting impact upon Jameson`s imaginative remolding of his conception of the real working of Marxist dialectics. Sartre's Marxist existentialism together with its complementing Althusserian concept of ideology with its Gramscian origin, as will be seen in the following part, has revealed the imaginative face of this code-switching mechanism of dialectics between form and content. In Marxism and Form, he refers to Sartre's theory of the "imaginary", which he sees as a reorganization of the object in such a way that it withdraws from the world of praxis and becomes not an action, but a gesture (396). So, at the hands of the artist or the historian or the critic, each in his field, the real world is transformed from reality into a symbolic gesture, in a way condensed into the number of factors Jameson has spoken of. As mentioned before, these elements have cohesion but are diachronically distanced. Practically speaking, the writer, for example, faces a conflict in society between wealthy factory owners and poor drudged workers, his next expected step is to extract the idea of wealthy versus poor and set them on an imaginary scale beginning with everything and ending with nothing. This imaginary scale is the quality intellectual domain of the writer which from the Marxist point of view domain should be dominated by the quantity 
collective domain of the socio-economic reality, folded upon it and constituting its external controlling form.

Socio-economic level

The scale of everything and nothing

For the writer, the poor dominated worker should be surrounded by a variety of the same type and the same applies to the opposite pole of the wealthy. These varieties represent different degrees on that deeper invisible intellectual scale so that their appearance creates of the polar characters typical ones and the others are mere distortions. The next step is to relate this characterization scale to the surface dominating socio-economic level, and this is the step where Sartre's thought interferes to modify the classical Marxist approach to literature. The traditional Marxist perspective sees these characters as mere representatives of their given class position, an attitude Jameson describes as allegorical and faulty (398). It is important to remember that these characters with the plot and the writer's point of view are means to reorganize this socio-economically informed content to reflect class conflict aiming at the emergence of mid-way position between poles. This midpoint is the symbolic conversion pot where opposites meet to give birth to a homogeneous middle class. So, after the first folding layer standing for the dominance of the socio-economic level, we witness a second fold, pulling the poles of the surface level to the middle of the deep symbolic but future concrete form represented in the following figure 


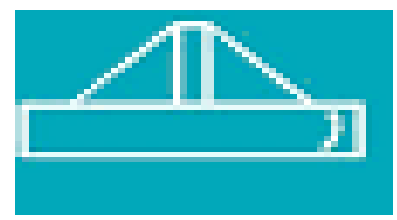

Now, the concrete socio-economic level has been inserted in the middle of the individual qualitative intellectual level of the writer/critic to endow it with the quantity dimension. In contrast to vulgar Marxism which sees life as the sole determining factor of man`s consciousness (326), Sartre and Althusser assign a role for the imaginary realm of ideology and freedom or responsibility. This insistence on the individual positive role in the imaginary reliving of class conflict springs from the difference in focus for both Marx and Sartre. While for the former, Marxism stresses the diachronic element, seeing classes in succession, thus donating them autonomy, the latter's main object is the synchronic existence of classes. This shouldn't be understood to mean that Sartre denies the diachronic element. On the contrary, but he sees class formation which takes place once the collective socioeconomic element is playing its formative role in the consciousness of the individual class as an alternative process of series and group structure. If the factory owners act bloodily against the workers, the felt resentment will be transferred to the next generations, leaving its actual traces on both the repressive legislative system on the one hand and a suspicion element eating up the repressed workers. This conflict will return to meet the following generations in an objective situation they have no freedom but to act against. As Jameson clarifies, they have interiorized the past violence in the form of an implicit oath of allegiance to their class. This real complete being denied the repressed class is transformed into a responsibility round which their total class lifestyle is organized (283). So, for Sartre the past 
injustice is a focal point leading the second generation to group around in a form of an oath. Following this line of thought, it could be seen that the confrontation between Being and Nothingness has forced certain elements to gather in a circle, while the others are still subject to the logical laws of cause and effect imposed by the selected few belonging to the world of Being. In a sense, the confrontation results in an ossification process of determined relations of absence and presence. Here, Jameson is establishing another difference between Sartre and Marx in the former`s priority given to the internal process taking place in man`s consciousness. This individual consciousness which has started its writing/reading process as an imaginary subject, selecting certain factors, believing them to be the determining elements of the rest, is transformed into an object before the "look" of the rest. The look meant here isn`t the actual visible presence of the dominating other, but rather an implicit transmitted structure (392).

What Sartre is aspiring to is to transform the economic factors into historical ones, so much so that what appeared as an inevitable situation of a binary opposition between the wealthy and the poor in its first appearance, is changing into a synchronic situation of a multiplicity of options the emerging middle class standing for a homogeneous position of consciousness enjoys. This multiplicity offers itself as a synchronic natural situation the assumed individual subject/object has to select from. This explains Jameson`s ambiguous statement that the middle -class man distinguishes himself by selection as an anti-nature process, while the bourgeois does this by suppression, by the dictatorship practiced on the body (286). The present situation Sartre has created is one of Marxist existential historicism, which as Jameson 
explains, isn't after origin or end but seeking the process of production and consumption, the event produced and introduced as inevitable and how it is consumed in a new transformed one of freedom of choice and a revelation of both the past in terms of memory and the present. In this existential historicist situation "every age is immediate to God" as Ranke`s dictum indicates (Jameson,The Ideology of Theory 156). Consequently, Sartre`s existential historicism has succeeded in liberating man from the linguistic prison of the present, by recalling the past and juxtaposing it with the present in the form of two languages ready to be mediated by the middle-class man in a form of translation.

This translating process has its place on the mythical level of existence, where myth here is understood to be new individual writing of the half-real and half conjured reality. Again Medusa myth comes to the surface standing for the past as a solidified and destructive reality that should be faced by a liquidation process that lends its past solidity to the present individual articulation

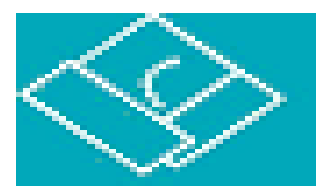

This diamond shape marks the new form headed by the individual consciousness whose content is the previous socioeconomic form. If existential Marxism stops at this point, then the whole project of dialectics is perceived as no more than an exchange of positions in a dramatic gesture of the past usurping the present throne, but the Marxist dialectics is after neutralization. It realizes that the form and content are not answers for the problem, but an articulation of it. Consequently, Jameson introduces the individual consciousness in an ethical figure of the vanishing mediator whose Sartrean motto is that the complete man 
is made up of everybody else, worth any of them, but no better any of them (Jameson, Marxism and Form 283). Conceiving his position in those terms of the whole and the part, his vision of the world is a doubled one of appearance and reality, hence his mission is twofold, one of action and another of prayer. In Marxism and Form, Jameson records the process as follows

"Know", says an ancient manuscript of the Zohar in this sense, that there exists for all worlds a double form of vision. One shows their exterior, the general laws of the worlds according to their outer form. The other shows their inner essence, namely the very essence of the human soul itself. works and that of prayer; for works are to fulfill the worlds in the respect of their external appearance, prayers to make the one world hold within the others and to lift them (157).

The vanishing mediator`s first mission as accomplished by the reader/writer is set in terms of Althusseran ideology, in the sense of relating the characters to the power structure in their society (167). This imaginary invisible web surrounding the individual is no more than the relations to the surrounding commodities, which when fully absorbed and consumed becomes a sort of belief (298). In this respect, the vanishing mediator helps in making visible these transparent invisible webs, and in getting these characters to their full typical form, through a narrative that lays bare all the possible options before each character.

With the introduction of the concept of ideology, the reader is in a better position to recall the earlier analogy of the insinuating forbidden tree, hiding the process of creation, and to see in it the external apparent vision of the world, while the real earthly one is the second internal vision. Existential Marxist 
dialectics sees both as two faces of one coin called ideology, an imaginary relation to a structure of power reflecting a deep hidden individual belief. This belief is reflected in the individual's relation to the surrounding objects which he consumes as commodities, but the Marxist dialectics reveals such consumption in terms of ideas out of its belief that things, even though presented as visible commodities, are consumed as ideas. Supporting such a belief is the existential Sartrean and Althusseran conception of ideology as a two-faced coin. On the one hand, it supports human beings, their gatherings, and grouping. On the other hand, it is a means of social resistance, of discrediting adversaries (380). In this respect, ideology is an existential proof of man's freedom of choice and the consequential belief resulting from this freedom.

Marxist dialectic's main focus isn't the positive aspect, but rather the negative one of ideology. So, again the Marxist Adam isn't satisfied with the honorary position of a subject in a human group because he has a venomous belief that he is merely a deceived object. As Jameson explains the "we- subject" doesn't have a genuine being. It is only the pre- text of we-object. Weobject defines itself in reaction to the we- subject, through a kind of defense mechanism (302). Dialectical Marxism is driven to such a conclusion in its search for the real cause of man`s numbed sense, something which Jameson sees as Marxism`s basic privilege over other theories, the one aspect that creates of it a constant revolutionary power that isn't satisfied with the apparent structure and always seeking a cognitive mapping of what Jameson calls the political unconscious. Practically speaking, in drinking a glass of alcohol, you aren 't just drinking a liquid, but a whole ideology which limits your horizon of expression, because what you see is only a layer, one layer of a whole process of labor 
presenting itself in terms of a mere commodity to be easily consumed. Here, we are driven into another fold of the diamond shape which juxtaposes past and present to remind of both neverto- be forgotten hidden element(idea) and of the superiority of weobject; the collective concrete situation.

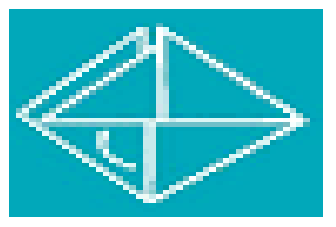

This resisting or revolutionary aspect of ideology is essentially anti-empiricist. As Jameson says, it drives the "wedge of the concept of a "text" into the traditional disciplines, by extrapolating the notion of "discourse" or writing onto the objects previously thought to be realities, or objects in the real world as the various levels or instances of a social formation" (Jameson, The Political Unconscious 278). What Jameson means to say is that dialectical Marxism has managed to juxtapose past and present, presence and absence, culture, and barbarism so what has been a finished written text is revealed to be an ongoing discourse. This result leads us directly to the second mission of the vanishing mediator: prayer. This second task raises us to another imaginary level tackled by Marxist dialectics; a twin of ideology: utopian vision. The Marxist utopia is no more than the realization that code-switching between absence and presence, form and content, various literary and critical schools are valence language; the middle -class language between apparent opposites which keeps emerging in every age as a defense mechanism and after a time, loses its therapeutic effect. In The Political Unconscious, Jameson says 
I would wish to argue the methodological proposition outlined here: that a Marxist negative hermeneutic, a Marxist practice of ideological analysis proper, must in the practical work of reading and interpretation be exercised simultaneously with a Marxist positive hermeneutic, or decipherment of the utopian impulses of these same still ideological cultural texts (286).

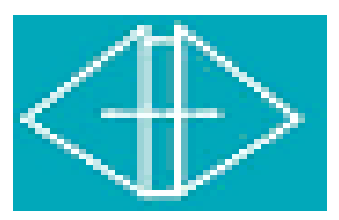

As it has been stated, the mediator's mission isn't restricted to the action field, which is ideologically translated into revealing the sub-web of controlling and conflicting social and economic ideologies, but it also extended to cover the prayer domain. Here, again we are guests to the imaginary world of Utopia built upon dialectical pillars. It is a very complicated domain because it marks the concepts of fate, value, and ethics. The first task assigned to the mediator has managed to reveal the hidden web controlling the traditional surface layer; the hidden tree of its past and fated creation: this is allegorically the realm of fate, of destination, in Marxist terms, of the infrastructure.

Bringing this level to the surface is a source of articulation and fulfillment. In Jameson's terminology, this is class consciousness as such (279). It is limited by the boundaries of class privilege which informs its immediate ideological vocation. Put in a simpler form, the writer/reader has set before us why this class behaves that way, he has brought to the surface both the synchronic and diachronic legacy of class struggle that makes this class what it is. Concomitant with this task, the writer/ reader has set this class its own utopian paradigmatic middle position. 
Grouping with the Frankfurt school, Jameson is after what may be called existential Sartrean freedom in the school's concept of instrumentalism (239). Jameson`s mediator, whom he likes to address in prophetic terms, in revealing the real legacy of the present class consciousness, has, in reality, helped it to realize its archetypal final form, something which should be interpreted in a transformational process of activity previously headed to an individual ethic into a universal value: an imaginary world of prayer in a struggle with the surface one of fate. The mediator`s effort has succeeded in such a leap because it has widened its scope of vision from the limited literary or cultural fields to that infinite one of time and history (287).

On the traditional level, which is interpreted as the surface one of class consciousness as such, class consciousness is one of duality, in which means are related directly to ends, a world of visibly embodied ethics that could be seen in a worker in direct contact with the product of his work, an allegory of first Adam whose primary passive materiality on which a manipulative operation works is involving a compensatory exchange: a world of abundance. But it is this proliferation or profusion characteristic of utopian vision and allegorical of man`s present state which causes the loss of the individual value. Therefore, the prophetic mediator is a must to restore value through an imaginary process of rationalization, which in Jameson`s words, is a process of constituting a common denominator to measure against (239). Consequently, we see that he resorts to Frankfurt's instrumentalism and commodification. Now, the mediator sees everything in terms of a commodity which the class consciousness either sells or buys, in return for which it gets an abstract value. This is the utopian instrumental free class consciousness that 
considers its work as the "conception and projection of a radically new form of some properly socialist legality that can't be achieved within the existing institution (288).

It is noteworthy that this ideology and utopia are considered twins for Jameson because as long as there is class consciousness as such, dominated by past or hidden ideological legacy, there is also a utopian one headed to the imaginary future, one is revealed by real historical analysis of static structures and the other is hinted at with the appearance of narrative memory which indicates, in contrast to historical analysis, the permanent possibility of change (Jameson, The Ideologies of Theory18). This dual vision of historical static structures and ever-changing narrative potentialities is the essence of meta-commentary, the last stage of dialectic analysis defined by Jameson as "a reflective operation proposed for staging the struggle within an individual literary and cultural text of various interpretations (x).

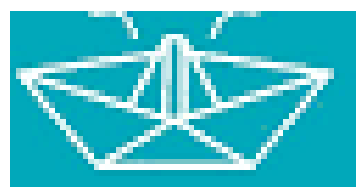

This is the idea of transcoding imposed upon the present situation of the proliferation, of codes characteristic of our world for which Jameson's belief that the mixture of vulgar Marxism and existential one is the best candidate for the job of articulating it. This mixture is nothing but postmodernism as the cultural logic of late capitalism we live in. In his book which bears the title of postmodernism as the cultural logic of late capitalism, Jameson provides a framework of a theory of stages of society, both economically and culturally. There are three basic economic stages of early market capitalism, followed by monopoly or imperialism and ending with the multinational capital of late 
capitalism. Jameson proceeds to read these expanding phases dialectically through the concomitant cultural stages of realism which bears the marks of Lukacs, modernism which he severely attacks, and finally postmodernism as the cultural logic of the present late capitalism.

This framework records the basic imaginary thumbprint of Jameson`s Marxism and its attempt to widen the scope for man`s utopian freedom. It starts with Lukacs` concept of a total historical hidden narrative as an open system and reification as the main mediator of capitalism (Jameson: a Critical reader xix). Jameson, following Lukacs, believes that narration is the basic function of the human mind, in the sense that it is the one necessary job to relate the different trajectories constituting the invisible web of the political collective unconscious. From this web, emerges the individual bourgeois subject with a reification process leading to commodification. In the second stage of modernism with its belief in autonomy and innovation, man has given up this narrative function for the sake of constant innovations that lack the collective project necessary for a real transformational change. These innovative steps are merely ruptures, preventing the human consciousness from tracing the invisible traces of the ever- opened narrative of history (xviii). While realism characteristic of the first stage is always heading to the past, to the lost world with its traces, the modern one is speeding to the future, the new even if it is rootless. Jameson considers the history of literature as a whole with its various theories as an alternative movement of subjectivity between the two trends, between ideology and utopia in a historicist attempt to build its own imaginary but authentic world. Literature is only one step on the way that prepares man to discover that the imaginary is the real he has created and believed 
in and that even though it is conditioned by the surrounding conditions, he still has the ability to change it. Once he reaches that stage of belief in the imaginary, he is well prepared to approach religion from a different perspective and to see in it both a restriction, and a complement to life (Jameson, Valence of Dialectic 164), exactly like the world of logic and forms. But more important is that man can both submit to and believe in its metaphysical aspects and at the same type keep questioning and interpreting them to articulate the hidden layers waiting for a mediator to constrict and extend them, thus donating them life.

Man`s history recorded in literature and culture with its material and spiritual faces, spatially divided and diachronically periodized still hides another unspoken one of ghosts, a negative dark one that Marxism with its dialectic tool has managed to transform into light signals to weave the two worlds in a historicist serial authentic but imaginary one of subjectivity. Fulfilling this objective, man has performed his own representative role as a cemetery guard as Derrida depicts the self in The Wolf Man. In The Wolf Man as Jameson says, a crypt is enclosed within the self. The self isn't the proprietor of what it guards, but it makes rounds and rounds driving people away and at the same time attracting them with the florescent (145).

Different interpretations presented at the hands of various theories, may appear to be defective on the long run, but they are the result of a syllogism process between the world of Being and that of Essence, in which the former is having its collective and historical standard of valence that the latter is only participating temporally in. So, in a sense they are neither false nor true, but they are as perfect as they should be in relation to a specific period, simply because they are the speaking soul of their age. 
These different forms and theories serve to periodize different historical epochs as Jameson indicates (Marxism and Form 512513) and to include them in a vaster structure or narrative (Anderson 54). In fact, these theories are true in relation to their age, for as Jameson says every age has its dominant truth (244), but their shortcomings which appear with years are merely their traces hunting consciousness to remind it of a different narrative still to be unfolded, another authentic historicist one in which everything whether past or future is presented as an immediacy to man as he is to a god. It is a stage in which man is a witness to his own offspring, his imaginary product, the trace that gives authenticity to his being, the one thing that Derrida affirms should be left at the end.

In its trace of Fredric Jameson`s Marxist theory, the paper has revealed that his Marxism with its dialectic is the transcode that both interprets the present and weaves it as a valence unity between imaginatively different worlds of the past and the future. It keeps leaping between the material present socio-economic reality as an equivalent unit and the past and the future as different abstract but imaginary homogeneous ones. Jameson`s Marxist dialectic is his own unique and essential human means of connecting things through the surrounding holes Sartre believed to surround groups. These holes, absences, ghosts are called to the stage of the present world of spectrally to play a different type of history, a non- linear spatial one having its folds between syllogism and daily life. It opens a Deleuzian Absolute world of potentialities of imagination. It is the postmodern world of endless multiplicities that man sees with his own eyes that paradoxically prepares him to accept both the unity and the metaphysical aspect of religion and no less significant to figure out his trace in this 
intricate web, a trace he leaves behind as a mark of his distinctive difference, for in contrast to nature as full immediacy, he has managed with his ghostly absence and presence to articulate both his own world and that of nature. 


\section{Works cited}

1. Althusser, Louis. Ideology and ideological state. Lenin and Philosophy, and Other Essays. B. Brewster, Trans. New York: Monthly Review Press, 1971. Print.

2. Anderson, Perry. The Origin of Postmodernity. London: Verso,1998. Print.

3. Buchanan, I. Fredric Jameson: Live Theory. London: Continuum, 2006. Print

4. Flisfeder, Matthew. "Conditions of Possibility: Jameson, Zizek and the Persistence of the Dialectic [review Essay]." Socialist Studies: The Journal of the Society for Socialist Studies vol. 6, no.1, Spring 2010, pp. 162- 168.

5. Homer, Sean and Douglas Kellner eds. Fredric Jameson: A Critical Reader. London: Palgrave Macmillan Ltd, 2004. Print.

6. Jameson, Fredric. Marxism and Form: Twentieth-century Dialectical Theories of Literature. Princeton, N.J: Princeton University Press, 1971. Print.

7. ----.-. The geopolitical aesthetic: Cinema and Space in the world system. London: British Film Institute, 1992. Print.

8. ---------. The Ideologies of Theory: Essays 1971-1986. In "vol.

2 Syntax of History" London: Routledge, 1988. Print.

9. ------.-. The Political Unconscious: narrative as a socially symbolic act. London: Routledge, 1983. Print 10. - ------. Valences of the Dialectic. London: Verso, 2009. Print. 
11. Qur'an, English. Translation of the Meanings of the Noble Qur'an in the English Language. [translated] by Muhammad Taqī-al-Dīn al-Hilālī and Muḥammad Mụ̣sin Khān. Madinah, K.S.A: King Fahd Complex For Printing of The Holy Qur`an. Print.

12. Tally Jr., Robert T. Fredric Jameson and Cultural Studies: Oxford Research Encyclopedia Communication. Oxford University Press, 2018.Print. 
الرموز الرئيسة في نظرية فريدريك جامسون النقدية

\author{
إعداد

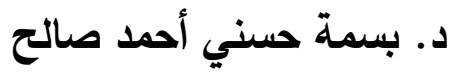 \\ مدرس النقد الأدبي بقسم اللغة الإنجليزية وآدابها \\ كلية الآداب - جامعة المنصورة
}

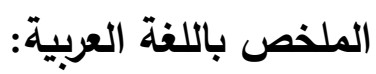

استهل فريدريك جامسون كتابه الثهير : (اللاوعي السياسي) بعبارة اقتبسها من

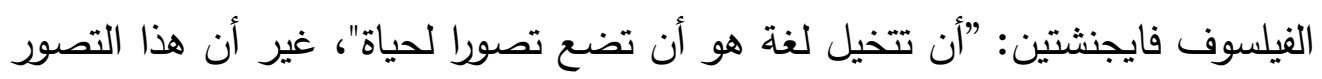

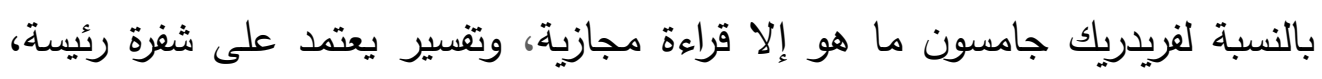

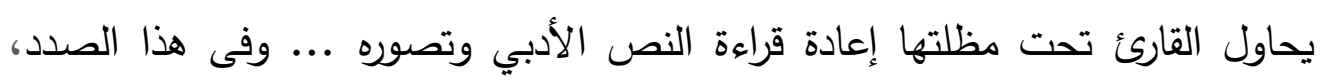

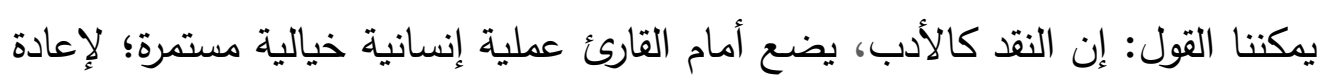

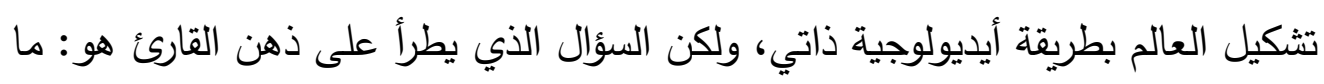

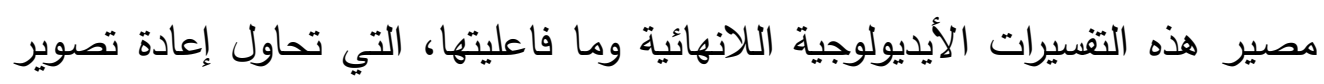

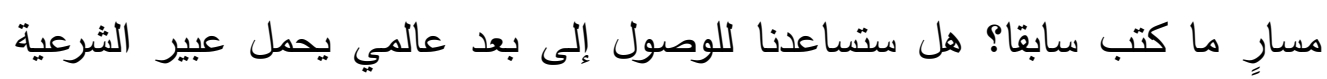

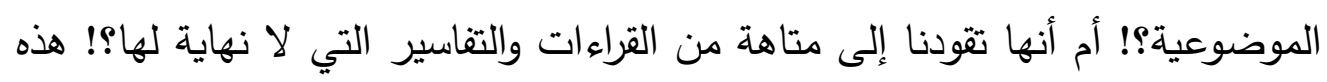

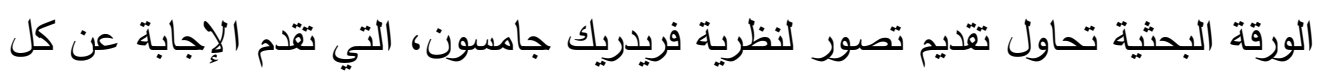

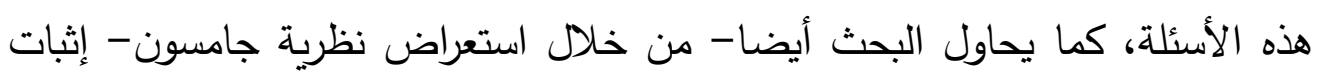

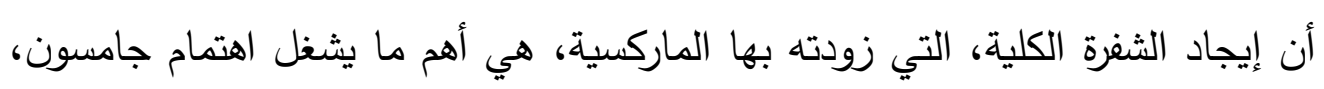

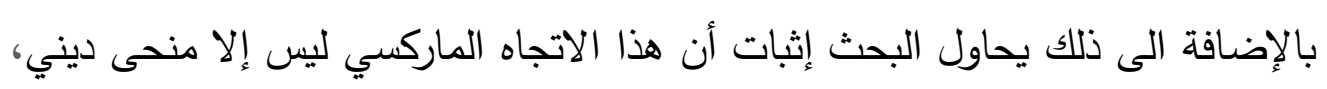

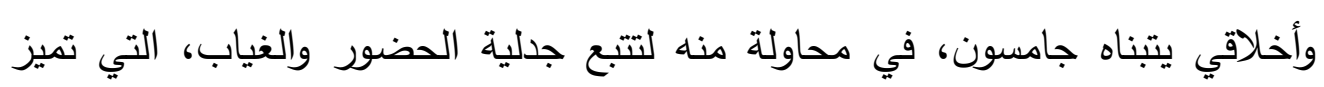
حركة التاريخ.

واعتمد البحث على النقد التأريخي والجدلي، الذي يتبناه نقد جامسون؛ كما

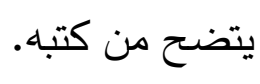
الكلمات المفتاحية: الأيديولوجية، التأويلية، التأريخية، الجدلية، اليوتوبيا . 